\title{
Analysis of selected primary metabolites and phenolic profile of 'Golden Delicious' apples from four production systems
}

\author{
Jerneja JAKOPIC $^{1 *}$, Ana SLATNAR ${ }^{1}$, Franci STAMPAR ${ }^{1}$, Robert Veberic ${ }^{1}$, Andrej SimonCIC ${ }^{2}$
}

${ }^{1}$ Biotech. Fac., Agron. Dep., Jamnikarjeva 101,

SI-1000 Ljubljana, Slovenia, Jerneja.Jakopic@bf.uni-lj.si

2 Agric. Inst. Slovenia, Hacquetova ulica 17, SI-1000 Ljubljana, Slovenia

${ }^{*}$ Correspondence and reprints

Received 6 October 2011 Accepted 12 December 2011

Fruits, 2012, vol. 67, p. 377-386 (C) 2012 Cirad/EDP Sciences All rights reserved DOI: 10.1051/fruits/2012032 www.fruits-journal.org

RESUMEN ESPAÑOL, p. 386

\section{Analysis of selected primary metabolites and phenolic profile of 'Golden} Delicious' apples from four production systems.

Abstract - Introduction. Apple fruit contains many compounds with positive effects on human health but even small pesticide residues from integrated production cause many food safety issues for consumers. Materials and methods. The apple fruits from different types of production: organic, integrated and two combined systems were analyzed. Their contents of sugars and organic acids were quantified with the use of HPLC with RI and UV detectors, and phenolic contents from apple skin and pulp were detected with HPLC-MS. Apple quality was also determined in terms of weight, firmness and color. Results. Organically produced fruits had 14\% lower weight than integrated fruits, as well as $15 \%$ higher firmness and less green skin color than apples from the other three treatments. Among primary metabolites, the sum of sugars (fructose, glucose, sucrose and sorbitol) as well as organic acids (malic and citric) was highest in the integrated production treatment. Among secondary metabolites, eighteen individual phenolic compounds were determined separately in apple peel and pulp. They were classified into four groups: hydroxycinnamic acids, flavan-3-ols, dihydrochalcones and flavonols. The majority of the identified compounds were dependent on the applied management system. Their concentrations were mainly highest in the organic treatment due to higher stress levels. The multivariate analysis of all monitored parameters placed organic production into one group and presented a similarity among the other three management systems.

Slovenia / Malus domestica / fruits / integrated plant production / organic agriculture / proximate composition / quality / Hplc

Analyse de certains métabolites primaires et du profil phénolique de pommes 'Golden Delicious' issues de quatre systèmes de production.

Résumé - Introduction. La pomme contient de nombreux composés ayant des effets positifs sur la santé humaine, mais les résidus, même faibles, de pesticides issus de productions intégrées provoquent de nombreux problèmes de sécurité alimentaire pour le consommateur. Matériel et méthodes. Les pommes issues de différents types de production (biologique, intégré et deux systèmes combinés de production) ont été analysées . Leur teneur en sucres et en acides organiques ont été quantifiées par utilisation de l'HPLC avec des détecteurs RI et UV ; les contenus phénoliques de la peau et de la chair des pommes ont été détectés par une HPLC-MS. La qualité des pommes a été également déterminée en termes de poids, fermeté et couleur du fruit. Résultats. Les fruits produits de façon biologique ont présenté un poids inférieur de $14 \%$ par rapport aux fruits produits par un système intégré; leur fermeté a été améliorée de $15 \%$ et leur couleur de peau a été moins verte que celle des pommes en provenance des trois autres traitements. Parmi les métabolites primaires, la somme des teneurs en sucres (fructose, glucose, saccharose et sorbitol) ainsi que celle des teneurs en acides organiques (acide malique et citrique) ont été les plus élevées pour les pommes issues de la production intégrée. Parmi les métabolites secondaires, dix-huit composés phénoliques individuels ont été déterminés séparément dans la peau et la chair des pommes. Ils ont été classés en quatre groupes: les acides hydroxycinnamiques, les flavan-3-ols, les dihydrochalcones et les flavonols. La majorité des composés identifiés ont été affectés par le système de gestion appliqué. Leurs concentrations ont principalement été les plus élevées dans les pommes produites de façon biologique en raison de niveaux de stress plus élevés. L'analyse multivariée de tous les paramètres étudiés a classé les fruits issus de production biologique dans un groupe à part et mis en évidence une similarité pour les productions des trois autres systèmes de production.

Slovénie / Malus domestica / Fruits / production végétale intégrée / agriculture biologique / composition globale / qualité / Hplc 


\section{Introduction}

In recent years, attention to the protection of the environment has been emphasized in food production. Integrated farming systems reduce the use of chemicals by integrating organic and conventional production methods and have been successfully adopted on a wide scale in Europe [1]. Organic management practices combine traditional conservation-minded farming methods with modern farming technologies but exclude such conventional inputs as synthetic pesticides and fertilizers, plant growth regulators, and genetically modified organisms [2].

Several authors have compared yield and fruit quality at harvest among organic, integrated and conventionally grown apples. While some authors found no substantial differences between apples from organic and integrated orchards in terms of yield and fruit size [2, 3], others have reported an overall better quality of organic apples compared with integrated or conventional apples [4-6]. However, organic yields were inconsistent, probably as the result of unsatisfactory crop load management, higher pest occurrence and weed pressures, as well as lower leaf and fruit tissue nitrogen levels [5]. The conventional and organic management systems resulted in similar fruit quality attributes, in terms of total soluble solids, juice $\mathrm{pH}$, titratable acidity and color indexes, while the conventionally grown trees produced almost twice the yield of the organically managed ones [7].

Apples are a rich source of phenolics. They have been reported as naturally occurring antioxidants, contributing against oxidative damage caused by free radicals which influence many chronic human diseases [8]. Their content and profile in fruit is influenced by several factors, including climate [9], the effects of light [10], cultivars [11], temperature, mineral nutrition, water management, grafting, application of elicitors, stimulating agents, plant activators [12] and exposure to various kinds of stress [13]. Veberic et al. established that organically grown apples exhibited a higher content of phenolic compounds in apple pulp compared with apples from integrated production [14]. This may be due to the absence of synthetic fertilizers, pesticides and thinners, that are not allowed in organic production. Therefore, organically grown plants are more exposed to environmental stress and form specific stress metabolites which could also contribute beneficially to fruit quality [13].

It is important to identify the production systems which positively affect their synthesis in plants and have minimal negative impact on the wider environment. The aim of our work was thus to compare the chemical composition of apples from different types of production: organic, integrated and two combined systems. In the last two production systems, no synthetic pesticides were used in the last few weeks before harvest. Weight, color, firmness, sugar content, organic acid content, and contents of individual phenolics in pulp and skin of the fruits were determined. With all these parameters the optimal management system for apple orchards in our climatic conditions in regard to their content of phenolic compounds can be determined.

\section{Materials and methods}

\subsection{Plant material}

Our study was performed on 3-year-old 'Golden Delicious' apple trees grafted on M9 rootstock grown in the experimental orchard of the Agricultural Institute of Slovenia in central Slovenia $\left(46^{\circ} 19^{\prime} \mathrm{N}, 14^{\circ} 67^{\prime} \mathrm{E}\right)$ in the growing season 2009 . The experiment included 60 trees cultivated according to commercial guidelines for integrated, organic or combination of two fruit productions. One-quarter of trees were cultivated according to organic production, the second quarter according to integrated production. The remaining trees were cultivated according to improved integrated production. All the measures and practices in the integrated orchard were carried out according to the pest management guidelines ${ }^{1}$, and organic production was managed according to the

\footnotetext{
${ }^{1}$ Rules on integrated production of fruit. Gov. Repub. Slov., Minist. Agric., For. Food, zakonodaja.gov.si/rpsi/r04/predpis_ PRAV6804.html [5 Jan. 2009].
} 
European Union Council Regulation [15]. Improved integrated production included the spraying program according to integrated guidelines until the end of July and then only Madex ( $1 \%$ granular virus) was used on one half of these trees (Madex) and on the other half, NeemAzal ( $1 \%$ azadirachtin A) was applied (Neem). After bloom all trees were thinned to equal crop load of 60 fruits per tree. Fruits from the middle five trees ( 5 fruits per tree; $n=5$ ) of each treatment were harvested at technological maturity and chemical analyses were performed.

\subsection{Fruit color measurements}

Apple color was measured using the Minolta CR-10 Chroma portable colorimeter (Minolta Co., Osaka, Japan). Fruit chromaticity was recorded in CIE (Commission Internationale d'Eclairage) parameters $L^{*}$, $a^{*}, b^{*}$ and hue angle $\left(\mathrm{h}^{\circ}\right)$ color space coordinates.

\subsection{Analysis of individual carbohydrates and organic acids}

The apple fruits were analyzed for the content of carbohydrates (sorbitol, sucrose, glucose and fructose) and organic acids (malic and citric acids). The stalk, sepal and core were removed from the fruit, and $10 \mathrm{~g}$ fresh weight (FW) was immersed into $50 \mathrm{~mL}$ of twice-distilled water and homogenized with a homogenizer (T25 basic Ultra-Turrax, IKA Labortechnik, Janke and Kunkel GmbH, Staufen, Germany).

Fruit samples were left extracting for half an hour at room temperature with frequent stirring. Samples were centrifuged for $7 \mathrm{~min}$ at $12,000 \times g$; the supernatants were filtered through a $0.45-\mu \mathrm{m}$ cellulose filter produced by Macherey-Nagel (Düren, Germany), poured into vials and analyzed using highperformance liquid chromatography (HPLC; Thermo Scientific, San Jose, CA, USA). For the analysis of organic acids, the Rezex ROAOrganic acid column $(300 \mathrm{~mm} \times 7.8 \mathrm{~mm})$ (Phenomenex, Torrance, CA, USA), heated to $65^{\circ} \mathrm{C}$, with $4 \mathrm{mM}$ sulfuric (VI) acid as the mobile phase and a UV detector, was used. For the determination of sugars, the Rezex
RCM-monosaccharide column $(300 \mathrm{~mm} \times$ $7.8 \mathrm{~mm}$ ) (Phenomenex, Torrance, CA, USA) heated to $65^{\circ} \mathrm{C}$, with bidistilled water as the mobile phase and a RI detector, was utilized. The concentrations were recalculated using the calibration curve of standards of known concentrations.

\subsection{Analysis of individual phenolics}

For the analysis of individual phenols, fresh apple peel and pulp were separately finely chopped. Five $g$ of peel and ten $g$ of pulp were extracted with $25 \mathrm{~mL}$ methanol containing 1\%(v/v) formic acid and 1\%(w/v) 2,6-di-tert-butyl-4-methylphenol (BHT) in a chilled ultrasonic bath for half an hour. After the extraction, the treated samples were centrifuged for $7 \mathrm{~min}$ at $12,000 \times \mathrm{g}$. The supernatant was filtered through the Chromafil AO-45/25 polyamide filter produced by Macherey-Nagel (Düren, Germany) and transferred into a vial prior to injection into the HPLC system.

Samples were analyzed on a Thermo Finnigan Surveyor HPLC-MS system (Thermo Scientific, San Jose, USA) using a Phenomenex HPLC column $\mathrm{C}_{18}(150 \mathrm{~mm} \times 4.6 \mathrm{~mm}$, Gemini $3 \mu \mathrm{m})$ as described in our previous papers [16].

\subsection{Analysis of total phenolics}

Extraction for the total phenolic content was performed in the same way as for individual phenolic compounds, but only methanol was used for the extraction. The total content was determined using FolinCiocalteu reagent [17] and spectrophotometrical measurements of absorbance at a wavelength of $765 \mathrm{~nm}$ were recorded. The total phenolic content was expressed as gallic acid equivalents (GAE) in $\mathrm{mg} \cdot \mathrm{kg}^{-1}$ fresh weight.

\subsection{Chemicals}

The following standard compounds were used: sucrose, fructose, glucose, sorbitol, malic and citric acid, quercetin 3-galactoside, quercetin 3-glucoside and quercetin 
Table I.

Weight, firmness and chromaticity values of skin color at harvest time of 'Golden Delicious' apples produced with four management systems [organic system, integrated system and two improved integrated production systems with application of Madex (1\% granular virus) or NeemAzal (1\% azadirachtin)].

$\begin{array}{lcccccc}\text { Treatments } & \begin{array}{c}\text { Weight } \\ (\mathrm{g})\end{array} & \begin{array}{c}\text { Firmness } \\ \left(\mathrm{kg} \cdot \mathrm{cm}^{-2}\right)\end{array} & a^{*} & b^{*} & \mathrm{~h}^{\circ} & L \\ \text { Organic } & 216 \pm 5 \mathrm{a} & 8.5 \pm 0.1 \mathrm{~b} & -4.7 \pm 0.7 \mathrm{c} & 39.5 \pm 0.6 \mathrm{a} & 95.6 \pm 1.0 \mathrm{a} & 63.0 \pm 0.4 \mathrm{a} \\ \text { Integrated } & 250 \pm 6 \mathrm{~b} & 7.4 \pm 0.2 \mathrm{a} & -12.2 \pm 0.9 \mathrm{~b} & 45.0 \pm 0.8 \mathrm{c} & 105.0 \pm 1.2 \mathrm{~b} & 65.5 \pm 0.4 \mathrm{~b} \\ \text { Madex } & 237 \pm 8 \mathrm{ab} & 7.4 \pm 0.1 \mathrm{a} & -19.0 \pm 0.3 \mathrm{a} & 40.4 \pm 0.3 \mathrm{a} & 115.2 \pm 0.4 \mathrm{c} & 65.2 \pm 0.4 \mathrm{~b} \\ \text { Neem } & 232 \pm 6 \mathrm{ab} & 7.5 \pm 0.1 \mathrm{a} & -17.7 \pm 0.5 \mathrm{a} & 42.3 \pm 0.4 \mathrm{~b} & 112.7 \pm 0.6 \mathrm{c} & 65.6 \pm 0.3 \mathrm{~b}\end{array}$

Average values \pm standard error are presented.

Different letters in columns mean statistically significant differences among the four production systems at $\alpha<0.05$.

3-rhamnoside from Fluka Chemie $\mathrm{GmbH}$ (Buchs, Switzerland); chlorogenic (5-caffeoylquinic) acid, quercetin, quercetin 3rutinoside (rutin) and (-)-epicatechin from Sigma-Aldrich Chemie GmbH (Steinheim, Germany); (+)-catechin from Roth (Karlsruhe, Germany); and quercetin 3xyloside and quercetin 3-arabinofuranoside from Apin Chemicals (Abingdon, UK).

Chemicals for the mobile phases were acetonitrile, formic acid and sulfuric acid from Fluka Chemie GmbH (Buchs, Switzerland).

The water used in sample preparation, solutions and analyses was twice-distilled and purified with a Milli-Q water purification system by Millipore (Bedford, MA, USA).

\subsection{Statistical evaluation}

Results were statistically analyzed with the Statgraphics Plus program for Windows 4.0, using one-way analysis of variance (ANOVA). The differences in content levels were estimated with Duncan's test. $P$-values of less than 0.05 were considered statistically significant.

Multivariate statistical analysis (hierarchical cluster analysis, discriminate analysis and classification) was conducted in order to interpret the differences in all analyzed compounds and four cultivation techniques. Ward's method based on squared Euclidian distance was used to interpret the differences in all analyzed compounds.

\section{Results and discussion}

\subsection{Analyses of weight, firmness and color of fruits}

The average fruit weight of apple produced in the integrated management system was $250 \mathrm{~g}$; it was statistically higher compared with apple from the organic production, where fruit weight was $216 \mathrm{~g}$ (table I). The weight of the fruits from the Neem and Madex treatments was in a range between organic and integrated production and did not statistically differ from any of them. Similar reports have been published by other authors who determined that fruits from organic production weigh less in comparison with fruit of conventional production [7].

Apple fruit firmness is one of the quality parameters [18] and presents one of the most important criteria for the consumers. The greater firmness of the organic production fruit would be advantageous in the market [5]. In the present study, organic apples had higher flesh firmness than apples from the integrated production (table I). Peck et al. also reported that organic apples were always rated as firm or firmer and had an equal or better texture than fruit from other production systems [5]. Conventional apples were generally rated less firm and had a poorer texture, while apples produced in the integrated management system were similar to those from organic production. No statistically significant differences among 
Table II.

Content levels of primary metabolites ( $\mathrm{mg} \cdot \mathrm{g}^{-1}$ fresh weight) in 'Golden Delicious' apples produced with four management systems [organic system, integrated system and two improved integrated production systems with application of Madex ( $1 \%$ granular virus) or NeemAzal (1\% azadirachtin)].

\begin{tabular}{|c|c|c|c|c|c|c|c|c|}
\hline \multirow[t]{2}{*}{ Treatment } & \multicolumn{4}{|c|}{ Sugars } & \multirow{2}{*}{$\begin{array}{c}\text { Sum } \\
\text { of sugars }\end{array}$} & \multicolumn{2}{|c|}{ Organic acids } & \multirow{2}{*}{$\begin{array}{c}\text { Sum } \\
\text { of organic acids }\end{array}$} \\
\hline & Fructose & Glucose & Suc & Sork & & Malic acid & Citric acid & \\
\hline Organic & $23.4 \pm 1.2 \mathrm{a}$ & $12.1 \pm 0.9 \mathrm{a}$ & $16.1 \pm 0.7 \mathrm{ab}$ & $1.9 \pm 0.2 c$ & $53.7 \pm 3.9 \mathrm{a}$ & $4.0 \pm 0.2 b$ & $1.4 \pm$ & 5.4 \\
\hline Integrated & $30.3 \pm 1.8 b$ & $20.4 b \pm 1.4 b$ & $19.4 \pm 0.9 c$ & $2.1 \pm 0.1 \mathrm{c}$ & $68.6 \pm 0.3 b$ & $4.0 \pm 0.1 b$ & $1.4 \pm 0.0 \mathrm{c}$ & $5.4 \pm 0.1 b$ \\
\hline Madex & $27.7 \pm 1.4 \mathrm{ab}$ & $13.0 \pm 1.3 \mathrm{a}$ & $13.8 \pm$ a $0.7 \mathrm{a}$ & $0.4 \pm 0.1 \mathrm{a}$ & $58.5 \pm 2.5 a b$ & $2.8 \pm 0.2 \mathrm{a}$ & $1.2 \pm 0.1 \mathrm{ab}$ & $4.0 \pm 0.2 \mathrm{a}$ \\
\hline Neem & $32.9 \pm 1.8 b$ & $14.2 \pm 0.6 \mathrm{a}$ & $17.5 \pm 0.8 b c$ & $1.0 \pm 0.3 b$ & $64.7 \pm 4.8 b$ & $3.1 \pm 0.2 \mathrm{a}$ & $1.1 \pm 0.1 \mathrm{a}$ & $4.2 \pm 0.2 \mathrm{a}$ \\
\hline
\end{tabular}

Average values \pm standard error are presented.

Different letters in columns mean statistically significant differences among the four production systems at $\alpha<0.05$.

the integrated, Madex and Neem treatments in fruit firmness were monitored.

Although some authors reported that fruits from organic and conventional practices exhibited similar peel color, these findings were not confirmed in our study [5]. Based on the colorimetrically defined parameters, fruit skin color differed between apples from the organic and integrated production. Parameter $b^{\circ}$ is defined on the scale from $0^{\circ}$ up to $360^{\circ}$, where $90^{\circ}$ is for yellow and $180^{\circ}$ for green color. The $b^{\circ}$ values of fruit from organic production were a little over $90^{\circ}$, which means that apples were more yellow. The $b^{\circ}$ values of apples produced in the integrated management system were statistically higher, while the highest values of this parameter were monitored in the Madex and Neem treatments. This means that apples from the Madex and Neem treatments were visually the greenest; apples of the integrated production were less green and those of the organic production were the least green of all.

\subsection{Contents of sugars and organic acids}

Among primary metabolites, four sugars and two organic acids were determined. The main share of total sugars in apple was presented by fructose (table II). A similar share of fructose in apple fruit has been reported by Mikulic Petkovsek et al. for the
'Golden Delicious' cultivar [19], but the content was higher compared with our results. In our study, significant differences among the analyzed production systems were observed. Apples from integrated production contained higher levels of total sugars, as well as a higher content of glucose, fructose and sucrose in comparison with organically produced apples. The contents of total sugar and fructose in the Madex and Neem treatments did not statistically differ from those measured in apples of integrated production. In the case of glucose and sucrose, the Madex and Neem treatments (both combinations of organic and integrated production) were similar to organic production. A minor part of total sugars is presented by sorbitol, and the content was not statistically different between apples from organic and integrated management systems.

Malic acid was the main organic acid in apple fruit, followed by citric acid. Total organic acid contents were highest in the integrated and organic production compared with the other treatments. The content of malic acid was similar in apples of organic and integrated production, and higher than in the apples of the Madex and Neem treatments. Roussos and Gasparatos compared organic and conventional apple production and did not find any differences in the titratable acidity between the two production practices [7]. In other comparative studies, conventional and integrated "Gala" 
Table III.

Content levels (mg. $\mathrm{kg}^{-1}$ fresh weight) of secondary metabolites in the peel of 'Golden Delicious' apples produced with four management systems [organic system, integrated system and two improved integrated production systems with application of Madex (1\% granular virus) or NeemAzal (1\% azadirachtin)].

$\begin{array}{lccccc}\text { Treatment } & \text { Hydroxycinnamic acids } & \text { Flavan-3-ols } & \text { Flavonols } & \text { Dihydrochalcones } & \text { Total phenolic content } \\ \text { Organic } & 281 \pm 19 \mathrm{c} & 808 \pm 58 \mathrm{~b} & 1969 \pm 122 \mathrm{~b} & 319 \pm 28 \mathrm{~b} & 1601 \pm 45 \mathrm{~b} \\ \text { Integrated } & 203 \pm 8 \mathrm{~b} & 563 \pm 26 \mathrm{a} & 2183 \pm 113 \mathrm{~b} & 223 \pm 16 \mathrm{a} & 1485 \pm 53 \mathrm{~b} \\ \text { Madex } & 167 \pm 12 \mathrm{a} & 586 \pm 34 \mathrm{a} & 1023 \pm 121 \mathrm{a} & 229 \pm 11 \mathrm{a} & 950 \pm 70 \mathrm{a} \\ \text { Neem } & 143 \pm 5 \mathrm{a} & 552 \pm 24 \mathrm{a} & 801 \pm 114 \mathrm{a} & 184 \pm 15 \mathrm{a} & 992 \pm 63 \mathrm{a}\end{array}$

Average values \pm standard error are presented.

Different letters in columns mean statistically significant differences among the four production systems at $\alpha<0.05$.

\section{Table IV.}

Content levels $\left(\mathrm{mg} \cdot \mathrm{kg}^{-1}\right.$ fresh weight) of secondary metabolites in the pulp of 'Golden Delicious' apples produced with four management systems [organic system, integrated system and two improved integrated production systems with application of Madex (1\% granular virus) or NeemAzal ( $1 \%$ azadirachtin)].

$\begin{array}{lccccc}\text { Treatment } & \text { Hydroxycinnamic acids } & \text { Flavan-3-ols } & \text { Flavonols } & \text { Dihydrochalcones } & \text { Total phenolic content } \\ \text { Organic } & 115 \pm 3 \mathrm{c} & 104 \pm 4 \mathrm{~b} & 12.2 \pm 0.7 \mathrm{~b} & 16.7 \pm 0.3 \mathrm{bc} & 212 \pm 6 \mathrm{~b} \\ \text { Integrated } & 102 \pm 3 \mathrm{~b} & 83 \pm 7 \mathrm{a} & 8.4 \pm 0.4 \mathrm{a} & 15.5 \pm 0.4 \mathrm{ab} & 145 \pm 7 \mathrm{a} \\ \text { Madex } & 84 \pm 4 \mathrm{a} & 70 \pm 3 \mathrm{a} & 8.6 \pm 0.5 \mathrm{a} & 17.8 \pm 0.4 \mathrm{c} & 134 \pm 6 \mathrm{a} \\ \text { Neem } & 93 \pm 3 \mathrm{ab} & 71 \pm 7 \mathrm{a} & 8.7 \pm 0.7 \mathrm{a} & 14.7 \pm 0.6 \mathrm{a} & 151 \pm 6 \mathrm{a}\end{array}$

Average values \pm standard error are presented.

Different letters in rows mean statistically significant differences among the four production systems at $\alpha<0.05$.

apples were found to have a lower titratable acidity than organic apples [5], but no differences were measured between organic and conventional 'Cortland' and 'McIntosh' apples [4].

\subsection{Analyses of phenolic compounds}

In our study, the 18 individual phenolic compounds from four groups of phenolic compounds, dihydrochalcones, flavan-3ols, hydroxycinnamic acids and flavonols, were determined. In all treatments, a higher content of individual phenolics as well as total phenolics was measured in apple peel as compared with the content in pulp (table III and IV). Many authors report the differences in the content of phenolic com- pounds in apple pulp compared with skin $[7,19,20]$. These findings confirm that apple phytoprotective compounds are mainly localized in the skin, which is the first barrier for pathogen penetration [21]. Similar results of phenol composition in apple were also obtained by Tsao et al. [22].

Three hydroxycinnamic acids were identified in apple peel and pulp: chlorogenic, caffeic and $4-p$-coumaroylquinic acid. Their sum was from $45 \%$ up to $60 \%$ lower in pulp than in peel and was dependent on the management system. In both peel and pulp, the highest concentrations were measured in apples of the organic production and were lower in apples of the integrated production. Even lower values were determined in the Madex and Neem treatments. Similarly, Mikulic Petkovsek et al. reported higher levels of hydroxycinnamic acids in organically 
produced apple cvs. 'Topaz' and 'Florina' in comparison with apples from integrated production [23]. In contrast, Chinnici et al. measured higher concentrations of hydroxycinnamic acids in apple cv. 'Golden Delicious' grown in integrated production than in apple from organic production [24].

Among flavan-3-ols, catechin, epicatechin, procyanidin $\mathrm{B} 1$ and procyanidin $\mathrm{B} 2$ were detected in apple peel. In pulp, in addition to the three determined in skin, an unidentified procyanidin dimer and a procyanidin trimer were detected. The flavan3-ols together with hydroxycinnamic acids presented the majority of total phenolic compounds in apple pulp. Also, in fruit peel, flavan-3-ols represented a high share in total phenolics. There were no differences in the content of flavan-3-ols in apple peel or pulp among the integrated, Madex and Neem treatments. Similar results from the three treatments indicate that the identical production practice until the end of July plays a key role in the contents of flavan-3ols in apple. On the other hand, organically produced apples contained 30\% more flavan-3-ols in apple peel and $20 \%$ more in apple pulp in comparison with apples from integrated production, respectively. Mikulic Petkovsek et al. also found higher contents of flavan-3-ols in three apple cultivars produced organically in comparison with apples from integrated production [23]. Plants in organic production are exposed to higher stress levels and, consequently, the synthesis of phenolic compounds in their fruit is thus greater. Namely, Slatnar et al. reported that apple peel infected with apple scab contained up to 3.9 times higher content of flavan-3-ols than healthy peel [25].

Among the dihydrochalcones, phloridzin and phloertin-2-xyloglucoside were identified in this group and the sum of their content ranged from $184 \mathrm{mg} \cdot \mathrm{kg}^{-1}$ fresh weight (Neem) to $319 \mathrm{mg} \cdot \mathrm{kg}^{-1}$ fresh weight (Organic) in peel and from $14.7 \mathrm{mg} \cdot \mathrm{kg}^{-1}$ fresh weight (Neem) to $17.8 \mathrm{mg} \cdot \mathrm{kg}^{-1}$ fresh weight (Madex) in pulp. Similarly, apples produced according to the organic practice contained higher levels of dihydrochalcones in the peel compared with integrated apples. The level of these compounds in apple peel from the Madex and Neem treatments was not statistically different than that obtained from the peel of integrated apples. In apple pulp, contents were much lower. Accumulation of phloridzin is in close correlation with pathogen pressure [21,26], which could explain higher values of dihydrochalcones in organic production where apples are more exposed to pathogens.

From the group of flavonols, seven quercetin 3-glycosides were determined in apple peel: quercetin 3-rutinoside, quercetin 3-galactoside, quercetin 3-glucoside, quercetin 3-arabinopyranoside, quercetin 3-arabinofuranoside, quercetin 3-rhamnoside and quercetin 3-xyloside. The same flavonols were determined in apple pulp with the exception of quercetin 3-rutinoside and quercetin 3-arabinopyranoside. Contents of flavonols in the peel ranged from $801 \mathrm{mg} \cdot \mathrm{kg}^{-1}$ fresh weight (Neem) to $2183 \mathrm{mg} \cdot \mathrm{kg}^{-1}$ fresh weight (integrated system) and represented the main portion of total phenolics in apple peel. In peel, there were no statistical differences in the content of flavonols between organic and integrated apples, but lower values were measured in apples from the Madex and Neem treatments. In apple pulp, contents of flavonols were essentially lower than in peel and, moreover, organically produced apples contained higher levels in comparison with the other three treatments. However, Chinnini et al., who compared contents of phenolic compounds in apple peel and pulp in regard to the applied management system, detected higher concentrations of flavonols in apples of integrated production compared with those produced organically, both in apple peel and pulp [24]. On the other hand, Slatnar et al. reported that the concentration of flavonols was not dependent on infection with apple scab [25] and Mikulic Petkovsek et al. determined that cultivars resistant to apple scab contained lower contents of quercetin 3rhamonoside [19]; flavonols may not play a key role in the defense against apple scab.

Similar to the higher levels of individual phenolic compounds in apple peel compared with pulp, much higher values of total phenolic content, using Folin-Ciocalteu phenol reagent, were measured in the peel. This is in accordance with findings 


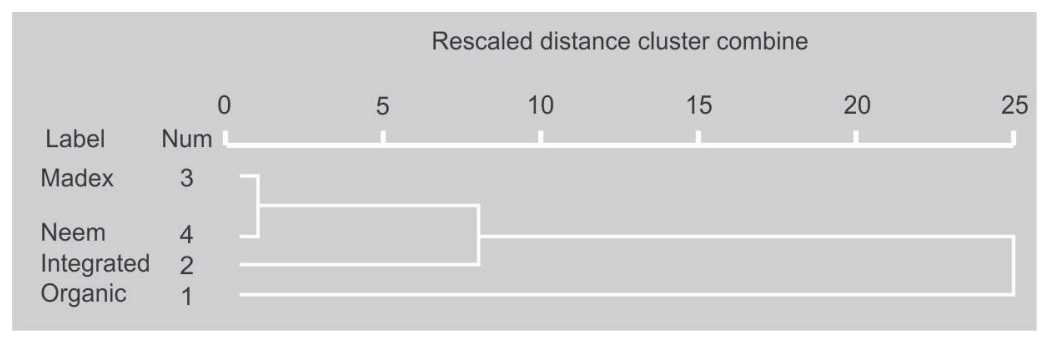

Figure 1.

Dendrogram for a mean value of carbohydrate, organic acid and phenolic contents for 'Golden Delicious' apples produced with four management systems [organic system, integrated system and two improved integrated production systems with application of Madex (1\% granular virus) or NeemAzal (1\% azadirachtin)], using Ward's method based on squared Euclidian distance.

previously obtained by other authors [7, 14, 19]. In the pulp of organically produced apples, a significantly higher total phenolic content was measured compared with the pulp of apple from the other three treatments, respectively. Total phenolic content measured in the peel of organically produced apples was also slightly higher but the differences were not statistically significant when compared with integrated production. However, in the peel of apples cultivated according to the Madex and Neem treatments, total phenolic content values were significantly lower.

According to many authors [14, 27, 28], higher phenol concentration in organically grown fruits can be attributed to severe forms of biotic or abiotic stress, which is known to induce phenolic biosynthesis. However, this theory cannot be applied universally, since there are examples in the literature where the content of phenolic compounds did not significantly differ between organically and conventionally produced fruit [7] or was even lower in organically produced fruit [29]. It is therefore very difficult to accurately define the effect of production technology on the formation of secondary metabolites, since there are a lot of different and unrelated factors influencing their concentration, such as ultraviolet radiation, low temperatures and nutrient deficiencies, as well as pest and pathogen attacks, which induce the production of antioxidants in plants [10, 21, 30, 31].

Typical differences in average values of all the analyzed parameters among treatments (Neem, Madex, organic and integrated production) were synthesized with a dendrogram obtained from a hierarchical cluster analysis (figure 1). Under the present experimental conditions, the management system significantly affected the major fruit quality attributes. Organic and integrated production were placed in two independent groups and there were no differences between the Madex and Neem treatments. Apples produced according to the integrated practices showed higher similarity to those grown according to Madex and Neem production than to apples of organic production. The similarities among the integrated practices, Madex and Neem treatments could be the consequence of identical production technology until the end of July in all three treatments. Several authors have published their results on the effect of management systems on fruit quality parameters [5, 14, 23]. According to most parameters analyzed in the study of Peck et al., the conventional and integrated farm management systems were more similar to each other than either was to the organic system [5]. The results of our study indicate that, despite limited use of organic technologies due to a lack of products for organic apple production, the organic apples showed significant improvements in some fruit quality attributes that could aid their marketability.

\section{Acknowledgments}

This work is part of the program Horticulture P4-0013-0481 supported by the Slovenian Ministry of Higher Education, Science and Technology.

\section{References}

[1] Sansavini S., Integrated fruit production in Europe: Research and strategies for a sustainable industry, Sci. Hortic.-Amsterdam 68 (1997) 25-36.

[2] Reganold J.P., Glover J.D., Andrews P.K., Hinman H.R., Sustainability of three apple production systems, Nature 410 (2001) 926930.

[3] Roth E., Berna A., Beullens K., Yarramraju S., Lammertyn J., Schenk A., Nicolai B., Postharvest quality of integrated and organically produced apple fruit, Postharvest Biol. Technol. 45 (2007) 11-19. 
[4] DeEll J.R., Prange R.K., Postharvest quality and sensory attributes of organically and conventionally grown apples, Hortscience 27 (1992) 1096-1099.

[5] Peck G.M., Andrews P.K., Reganold J.P., Fellman J.K., Apple orchard productivity and fruit quality under organic, conventional, and integrated management, Hortscience 41 (2006) 99-107.

[6] Amarante C.V.T. do, Steffens C.A., Mafra A.L., Albuquerque J.A., Yield and fruit quality of apple from conventional and organic production systems, Pesqui. Agropecu. Bras. 43 (2008) 333-340.

[7] Roussos P.A., Gasparatos D., Apple tree growth and overall fruit quality under organic and conventional orchard management, Sci. Hortic. Amsterdam 123 (2009) 247-252.

[8] Lee K.W., Kim Y.J., Kim D.O., Lee H.J., Lee C.Y., Major phenolics in apple and their contribution to the total antioxidant capacity, J. Agric. Food Chem. 51 (2003) 6516-6520.

[9] Stracke B.A., Rufer C.E., Weibel F.P., Bub A., Watzl B., Three-year comparison of the polyphenol contents and antioxidant capacities in organically and conventionally produced apples (Malus domestica Bork. cultivar 'Golden Delicious'), J. Agric. Food Chem. 57 (2009) 4598-4605.

[10] Jakopic J., Stampar F., Veberic R., The influence of exposure to light on the phenolic content of 'Fuji' apple, Sci. Hortic.-Amsterdam 123 (2009) 234-239.

[11] Nour V., Trandafir I., Ionica M.E., Ascorbic acid, anthocyanins, organic acids and mineral content of some black and red currant cultivars, Fruits 66 (2011) 353-362.

[12] Treutter D., Managing phenol contents in crop plants by phytochemical farming and breeding-visions and constraints, Int. J. Mol. Sci. 11 (2010) 807-857.

[13] Treutter D., Biosynthesis of phenolic compounds and its regulation in apple, Plant Growth Regul. 34 (2001) 71-89.

[14] Veberic R., Trobec M., Herbinger K., Hofer M., Grill D., Stampar F., Phenolic compounds in some apple (Malus domestica Borkh) cultivars of organic and integrated production, $\mathrm{J}$. Sci. Food Agric. 85 (2005) 1687-1694.

[15] Anon., Council Regulation (EC) No. 834/2007 of 28 June 2007 on organic production and labelling of organic products and repealing
Regulation (EEC) No. 2092/91, Eur. Comm., Brux., Belg., 2009.

[16] Jakopic J., Veberic R., Stampar F., Effect of reflective foil and hail nets on the lighting, color and anthocyanins of 'Fuji' apple, Sci. Hortic.-Amsterdam 115 (2007) 40-46.

[17] Singleton V.L., Rossi J.A.J., Colorimetry of total phenolics with phosphomolybdicphosphotungstic acid reagents, Am. J. Enol. Vitic. 16 (1965) 144-158.

[18] Magazin N., Gvozdenovic D., Keserovic Z., Milic B., Fruit quality of Granny Smith apples picked at different harvest times and treated with 1-MCP, Fruits 65 (2010) 191-197.

[19] Mikulic Petkovsek M., Stampar F., Veberic R., Parameters of inner quality of the apple scab resistant and susceptible apple cultivars (Malus domestica Borkh.), Sci. Hortic. -Amsterdam 114 (2007) 37-44.

[20] Lata B., Trampczynska A., Paczesna J., Cultivar variation in apple peel and whole fruit phenolic composition, Sci. Hortic. -Amsterdam 121 (2009) 176-181.

[21] Schovankova J., Opatova H., Changes in phenols composition and activity of phenylalanine-ammonia lyase in apples after fungal infections, Hortic. Sci. 38 (2011) 1-10.

[22] Tsao R., Yang R., Christopher J., Zhu Y., Zhu H.H., Polyphenolic profiles in eight apple cultivars using high-performance liquid chromatography (HPLC), J. Agric. Food Chem. 51 (2003) 6347-6353.

[23] Mikulic Petkovsek M., Slatnar A., Stampar F., Veberic R., The influence of organic/integrated production on the content of phenolic compounds in apple leaves and fruits in four different varieties over a 2-year period, J. Sci. Food Agric. 90 (2010) 2366-2378.

[24] Chinnici F., Bendini A., Gaiani A., Riponi C., Radical scavenging activities of peels and pulps from cv. Golden Delicious apples as related to their phenolic composition, J. Agric. Food Chem. 52 (2004) 4684-4689.

[25] Slatnar A., Petkovsek M.M., Halbwirth H., Stampar F., Stich K., Veberic R., Response of the phenylpropanoid pathway to Venturia inaequalis infection in maturing fruit of 'Braeburn' apple, J. Hortic. Sci. Biotechnol. 85 (2010) 465-472.

[26] Petkovsek M.M., Stampar F., Veberic R., Increased phenolic content in apple leaves infected with the apple scab pathogen, J. Plant Pathol. 90 (2008) 49-55. 
[27] Carbonaro M., Mattera M., Polyphenoloxidase activity and polyphenol levels in organically and conventionally grown peach (Prunus persica L., cv. Regina bianca) and pear (Pyrus communis L., Cv. Williams), Food Chem. 72 (2001) 419-424.

[28] Young J.E., Zhao X., Carey E.E., Welti R., Yang S.S., Wang W.Q., Phytochemical phenolics in organically grown vegetables, Mol. Nutr. Food Res. 49 (2005) 1136-1142.

[29] Amor F.M. del, Serrano-Martinez A., Fortea I., Nunez-Delicado E., Differential effect of organic cultivation on the levels of phenolics, peroxidase and capsidiol in sweet peppers, J. Sci. Food Agric. 88 (2008) 770-777.

[30] Matsuki M., Regulation of plant phenolic synthesis: From biochemistry to ecology and evolution, Aust. J. Bot. 44 (1996) 613-634.

[31] Yuri J.A., Neira A., Quilodran A., Motomura Y., Palomo I., Antioxidant activity and total phenolics concentration in apple peel and flesh is determined by cultivar and agroclimatic growing regions in Chile, J. Food Agric. Environ. 7 (2009) 513-517.

\section{Análisis de ciertos metabolitos primarios y del perfil fenólico de manzanas 'Golden Delicious' procedentes de cuatro sistemas de producción.}

Resumen - Introducción. La manzana contiene numerosos compuestos con efectos positivos en la salud del hombre, pero, por muy escasos que sean, los residuos de pesticidas procedentes de producciones integradas provocan numerosos problemas de seguridad alimentaria para el consumidor. Material y métodos. Se analizaron las manzanas procedentes de diferentes tipos de producción (biológica, integrada y dos sistemas combinados de producción). Se cuantificó su contenido en azúcares y ácidos orgánicos mediante uso de HPLC con detectores IR y UV; se detectaron los contenidos fenólicos de la piel y pulpa de las manzanas mediante HPLC-MS. Se determinó igualmente la calidad de las manzanas en términos de peso, firmeza y color del fruto. Resultados. Los frutos producidos de modo biológico presentaron un peso de un $14 \%$ inferior en relación con los frutos producidos por un sistema integrado; su firmeza se mejoró de un $15 \%$ y su color de piel fue menos verde que el de las manzanas procedentes de los otros tres tratamientos. Entre los metabolitos primarios, la suma de los contenidos en azúcares (fructosa, glucosa, sacarosa y sorbitol) así como la de los contenidos en ácidos orgánicos (ácido málico y crítico) fue la mayor para las manzanas procedentes de la producción integrada. Entre los metabolitos secundarios, se determinaron separadamente, en la piel y pulpa de las manzanas, diez y ocho compuestos fenólicos individuales. Fueron clasificados en cuatro grupos: los ácidos hidroxicinámicos, los flavan-3-oles, las dihidrochalconas y los flavonoles. La mayoría de los compuestos identificados fueron afectados por el sistema de gestión aplicado. Sus concentraciones fueron principalmente las más altas en las manzanas producidas de manera biológica, dados los mayores niveles de estrés. El análisis multivariado de todos los parámetros estudiados clasificó los frutos procedentes de la producción biológica en un grupo aparte y puso de manifiesto una similitud entre las producciones de los otros tres sistemas de producción.

Eslovenia / Malus domestica / frutas / producción vegetal integrada / agricultura orgánica / composición aproximada / calidad / Hplc 